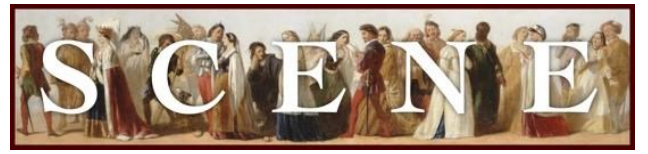

\title{
World Premiere of The Book of Will, by Lauren Gunderson
}

by Jim Volz. Written on 2017-03-06. Published in 2017 Issue 1.

For the production: The Book of Will (2017, Denver Center Theatre, USA).

AUdiENCE EXPECTATIONS ALWAYS SEEM AS HIGH FOR PLAYS ABOUT SHAKESPEARE AS THEY ARE for plays by Shakespeare which is, of course, an unfortunate reality for any contemporary playwright charged with competing with the likes of Romeo and Juliet, Hamlet, or King Lear. Whether it's the silliness of Paul Rudnick's I Hate Hamlet, the precociousness of Amy Freed's The Beard of Avon or the risque romance of Lee Hall's adaptation of Shakespeare in Love (based on the screenplay by Marc Norman and Tom Stoppard), there's always a bit of disappointment on the way out the door.

It's 1619-1623, London, England and Shakespeare's scripts are being bludgeoned, rewritten and/or ripped to shreds by actors and companies who have pirated pieces of the original scripts to make a quick buck in a land without copyrights. It's really not all that different than 21stcentury Shakespeare festivals where authors, actors, theatre and film directors mangle the scripts and don't have to tangle with the original playwright (or pay royalties)! The one huge exception is that in 1619, Shakespeare has loyal followers who knew him, respect his work, memorized his lines and shaped the work with the Bard in the room.

Lauren Gunderson certainly does her homework on the importance of the First Folio, the mechanics of gathering individual scripts and actually putting them into print and the immense challenges Shakespeare's fellow actors, John Heminges and Henry Condell, must have faced from a personal and financial point of view. We are often reminded of their loyalty and commitment to Will's legacy and Ms. Gunderson creates lively and sometimes larger than life characters and caricatures of such notable theatre figures as playwright Ben Jonson, actor Richard Burbage and scribe Ralph Crane (often credited with rescuing so much of the Bard's work through his skillful transcriptions).

The Denver Center Theatre world premiere of The Book of Will, directed by Davis McCallum, is clever, engaging and generally fast-paced but often works too hard to recreate a boisterous Jacobean frat party when trusting the words and simply telling the story might have been more 
effective. Triney Sandoval's blustering Burbage plays at a whole other level than others on stage and his doubling as Ben Jonson and tripling as Horatio are masterful but need a director's hand in shaping the characters for the intimate Denver Center's Ricketson Theatre.

The play's best moments are its quieter, sweeter moments when Liam Craig and Nancy Williamson as John and Rebecca Heminges and Kurt Rhoads as Henry Condell debate the task that lies before them and how it will impact their lives. Andy Nagraj as Isaac Jaggard surprises as the potentially evil publisher turned stand-up citizen. His quiet sincerity and Rodney Lizcano's wonderfully taciturn Ralph Crane kept the audience intrigued and added some drama to the publication we all know will eventually be printed. Miriam A. Laube, Thaddeus Fitzpatrick, Wesley Mann, and Jennifer Le Blanc round out this exceptionally talented, seasoned ensemble.

The Book of Will will no doubt be a favorite of artistic directors and fervent Shakespeare followers. Only time will tell if general audiences will be up for the story of two guys who just wanted to make sure their friend's remarkable tales would survive. However, with a cast of only ten actors, it's one of the more affordable "Shakespeare plays" and it is indeed a tale worth the telling.

(Review courtesy of the STA journal, Quarto)

Jim Volz is an international arts consultant, author, producer, and professor based in Orange County at California State University, Fullerton. He served as a longtime critic/arts columnist for New York's Back Stage and founding editor of the Shakespeare Theatre Association's international magazine, Quarto. He has produced over 100 professional productions, consulted for over 100 arts institutions and published more than 100 articles on management, arts criticism, Shakespeare, and theatre in American Theatre, Oxford University Press's Theatre Research International, Hollywood's Drama-Logue and myriad other articles for national and international publications. He is a Ph.D. graduate from the University of Colorado,Boulder.jvolz@fullerton.edu 